\title{
ANALISIS TINGKAT KERUSAKAN SERANGAN HAMA DAN PENYAKIT DIPERSEMAIAN BPDASHL INDRAGIRI ROKAN PEKANBARU
}

\author{
Analysis of the Damage Level of Pests and Diseases in BPDASHL Indragiri Rokan \\ Pekanbaru's Nursery
}

\author{
Azwin $^{1)}$, Eni Suhesti ${ }^{2)}$, Ervayenri ${ }^{3)}$ \\ ${ }^{123)}$ Dosen Fakultas Kehutanan Universitas Lancang Kuning \\ Jln. Yos Sudarso Km. 8 Rumbai Pekanbaru Riau
}

Email:azwin@unilak.ac.id,suhestieni@unilak.ac.id,erva@unilak.ac.id

Diterima: 08 November 2021, Direvisi: 10 Januari 2022, Disetujui: 29 Januari 2022

DOI: $10.31849 /$ forestra.v17i1.8376

\begin{abstract}
The presence of pests and diseases on plant seeds is one of the limiting factors for success in planting activities. Identification of pests and diseases needs to be done. This study aims to determine the level of damage caused by pests and diseases in BPDASHL Indragiri Rokan nursery. The data collection technique was carried out by means of a census of 4 types of seeds (Karas, Kepayang, Jengkol and Petai), in each bed containing 6000 seeds for each type. The results showed that the pests found were based on the symptoms caused. The frequency of pest attacks on caras, kepayang, jengkol and petai seedlings was an average of $22.01 \%$, including the category of light damage. The frequency of disease attacks on caras, kepayang, jengkol and petai seedlings was on average $26.23 \%$ including the moderately damaged category. The intensity of pest attack on caras, kepayang, jengkol and petai seedlings was an average of $17.88 \%$, including the category of light damage. The intensity of disease attack on the seeds of caras, kepayang, jengkol and petai on average was $22.77 \%$, including the category of lightly damaged.
\end{abstract}

Keywords: Pests and Diseases, Karas Seeds, Kepayang Seeds, Jengkol Seeds, Petai Seeds

\begin{abstract}
ABSTRAK
Adanya serangan hama dan penyakit pada bibit tanaman merupakan salah satu faktor pembatas keberhasilan dalam kegiatan penanaman. Indentifikasi terhadap serangan hama dan penyakit perlu dilakukan. Penelitian ini bertujuan mengetahui tingkat kerusakan akibat serangan hama dan penyakit dipersemaian BPDASHL Indragiri Rokan. Teknik pengambilan data dilakukan dengan cara sensus terhadap 4 jenis bibit (Karas, Kepayang, Jengkol dan Petai), pada setiap bedeng berisi 6000 bibit untuk setiap jenisnya. Hasil penelitian menunjukkan bahwa hama yang ditemukan berdasarkan gejala ditimbulkan. Frekwensi serangan hama pada bibit karas,
\end{abstract}


kepayang, jengkol dan petai rata-rata sebesar 22,01\% termasuk kategori rusak ringan. Frekwensi serangan penyakit pada bibit karas, kepayang, jengkol dan petai rata-rata sebesar 26,23\% termasuk kategori rusak sedang. Intensitas serangan hama pada bibit karas, kepayang, jengkol dan petai rata-rata sebesar 17,88\% termasuk kategori rusak ringan. Intensitas serangan penyakit pada bibit karas, kepayang, jengkol dan petai rata-rata sebesar $22,77 \%$ termasuk kategori rusak ringan.

Kata Kunci: Hama dan Penyakit, Bibit Karas, Bibit Kepayang, Bibit Jengkol, Bibit Petai

\section{PENDAHULUAN}

\section{Balai Pengelolaan Daerah Aliran} Sungai dan Hutan Lindung (BPDASHL) Indragiri Rokan Pekanbaru merupakan salah satu balai yang menyelenggarakan kegiatan persemaian dalam jumlah yang besar. Satriani (2020) menyatakan bahwa bibit yang diproduksi di persemaian permanen diharapkan memiliki sistem perakaran yang kompak dan terarah, sehat, struktur seimbang antara batang dan akar.

Salah satu faktor pembatas dalam keberhasilan tanaman untuk tumbuh optimal yaitu adanya serangan hama dan penyakit. Serangan hama dan penyakit dapat terjadi pada benih, bibit dan tanaman di lapangan. Serangan hama dan penyakit yang menyerang persemaian dapat mengganggu pertumbuhan dan mengurangi kualitas bibit bahkan dapat menyebabkan kematian bibit (Suharti, 2015). Serangga merupakan penyebab kerusakan pada bagian tanaman. Serangga dapat dikatakan sebagai hama apabila dapat merugikan tanaman secara fisiologis dan secara ekonomis (Asmaliyah dalam Koteng, 2019).

Dalam rangka pelestarian hutan dan lingkungan. Bibit tanaman dikatakan berkualitas apabila pertumbuhannya baik serta bebas dari serangan hama dan penyakit. Oleh karena itu, indentifikasi terhadap serangan hama dan penyakit perlu dilakukan dalam rangka menekan jumlah yang terserang sehingga tidak menimbulkan kerugian. Pentingnya mengidentifikasi hama dan penyakit yang disebabkan oleh patogen baik biotik maupun abiotik sangat diperlukan untuk mengetahui cara mengidentifkasinya dan cara penanggulangannya (Triwibowo, 2014).

Tujuan penelitian ini adalah untuk menganalisis tingkat kerusakan akibat serangan hama dan penyakit dipersemaian BPDASHL Indragiri Rokan Pekanbaru berdasarkan gejala yang ditimbulkan. 


\section{METODE PENELITIAN}

\subsection{Tempat dan Waktu Penelitian}

Penelitian ini dilaksanakan di Persemaian BPDASHL Indragiri Rokan Pekanbaru, dimulai pada Bulan MaretAgustus 2021.

\subsection{Pengambilan Data}

Teknik pengambilan data yang dilakukan dengan cara sensus terhadap semua bibit yang ada dibedengan pembibitan sesuai dengan jenisnya. Jumlah bibit yang diamati untuk setiap jenisnya sebanyak 6000 yang terdiri dari jenis bibit karas, kepayang, jengkol dan petai.

\subsection{Identifikasi Hama}

Untuk mengetahui jenis hama yang menyerang dilakukan observasi langsung dilapangan sesuai dengan gejala yang ditimbulkan. Setiap individu tanaman diamati dan ditentukan nilainya (skor) berdasarkan kondisi tanaman dan gejala serangan (Tabel 1).

Tabel 1. Penentukan Nilai (skor) Terhadap Gejala Serangan Hama

\begin{tabular}{lll}
\hline No & Gejala pada Tanaman & Skor \\
\hline 1 & Sehat (tidak ada gejala serangan) & 0 \\
2 & $\begin{array}{l}\text { Kurang sehat (adanya sedikit serangan dari keseluran daun) } \\
3\end{array}$ & 1 \\
Tidak sehat (adanya serangan lebih dari separoh besar daun daun dan & 2 \\
adanya rontok pada daun) & $\begin{array}{l}\text { Sangat tidak sehat (adanya serangan keseluruhan daun dan } \\
\text { mengakibatkan kerontokan pada daun }\end{array}$ \\
Mati (seluruh daun layuh dan rontok dan tidak ada tanda tanda \\
kehidupan)
\end{tabular}

\subsection{Identifikasi Penyakit}

Pada penelitian ini identifikasi ditentukan dengan kriteria seperti yang terdapat pada Tabel 2. penyakit yang merusak bibit tanaman

Tabel 2. Penentukan Nilai (skor) terhadap Gejala Serangan Penyakit.

\begin{tabular}{lll}
\hline No & Penyakit tanaman & Skor \\
\hline 1 & Sehat & 0 \\
2 & Bercak daun & 1 \\
3 & Daun gugur & 2
\end{tabular}


4 Daun kering dan rontok 3

5 Pucuk mati tidak ada tanda-tanda kehidupan 4

\subsection{Analisis Data}

\section{Frekuensi Serangan (FS)}

Frekuensi serangan (FS) dihitung dengan rumus dan dinyatakan dalam persen $(\%)$ sebagai berikut:

$$
\mathrm{FS}=\frac{Y}{X} \times 100 \%
$$

Keterangan:

FS : Frekuensi serangan

Y : Jumlah bibit yang terserang

$\mathrm{X}$ : Jumlah bibit yang diamati

\section{Intensitas Serangan (IS)}

Intensitas serangan (IS) dihitung dengan menggunakan rumus (Triwibowo, 2014) sebagai berikut:

$$
I S=\frac{\mathrm{X} 1 \mathrm{Y} 1+\mathrm{X} 2 \mathrm{Y} 2+\mathrm{X} 3 \mathrm{Y} 3+\mathrm{X} 4 \mathrm{Y} 4}{\mathrm{XY}} \times 100 \%
$$

Untuk menggambarkan kondisi bibit secara keseluruhan akibat serangan patogen dapat diketahui berdasarkan kriteria seperti terdapat dapat dilihat pada Tabel 3.

Tabel 3. Cara Menentukan Kondisi Bibit Akibat Serangan Hama

\begin{tabular}{ll}
\hline Intensitas Serangan & Kondidsi bibit \\
\hline $0-1$ & Sehat (s) \\
$>2-25$ & Rusak ringan (RR) \\
$>26-50$ & Rusak sedang (RS) \\
$>51-75$ & Rusak Berat (RB) \\
$>76-100$ & Rusak sangat berat (RSB) \\
\hline
\end{tabular}

III. HASIL DAN PEMBAHASAN

\section{A. Gejala Serangan Hama Bibit Karas}

Hasil identifikasi gejala serangan hama dan penyakit pada bibit karas di persemain BPDASHL terdapat gejala serangan daun bintik-bintik hitam, daun berlubang dan daun menggulung. Secara umum gejala serangan hama yang ditemukan digolongkan kedalam hama pemakan daun. Gejala serangan hama pemakan daun dapat dilihat dengan adanya daun berlobang, bintik-bintik dan tergunting.

\section{Daun Bintik-bintik Hitam}

Bintik-bintik hitam pada daun bibit tanaman karas telah menimbulkan kerugian bagi 
usaha pembibitan di persemaian BPDASHL yaitu pada penurunan kualitas bibit karas, sehingga berdampak buruk kepada jumlah bibit yang tersedia di persemain tersebut. Hasil identifikasi gejala serangan daun bintik-bintik hitam dapat terlihat pada daun muda. Gejala serangan hama bintik-bintik hitam pada bibit karas menunjukkan gejala awalnya terdapat di permukaan daun dan bawah daun, bentuk bintik-bintik hitam bervariasi mulai dari bentuk bulat sampai bentuk tidak beraturan, bintik-bintik hitam pada bibit karas disebabkan oleh suntikan atau serangan hama walang sangit, karena pada saat melakukan identifikasi gejala serangan di jumpai hama tersebut.

\section{Daun Berlubang}

Berdasarkan hasil pengamatan di lapangan, gejala serangan daun berlubang disebabkan oleh belalang (Oxya spp), daun yang terkena serangan umumnya daun yang masih muda, karena daun yang masih muda lunak. Pada kerusakan yang lebih parah daun akan menguning keriput yang hanya akan menyisakan tulang daunnya saja akibat bekas gigitan belalang kemudian daun akan layu. Belalang hanya memakan sebagian dari daun tidak seluruhnya bagian daun dimakan. Serangan hama belalang mengakibatkan berkurangnya luasan permukaan daun yang dapat menghambat proses fisiologi karena daun merupakan tempat berlangsungnya proses fotosintesis.

\section{Daun Menggulung}

Dari hasil pengamatan di lapangan ditemukan gejala serangan daun menggulung, daun menggulung disebabkan oleh hama laba-laba, hama laba-laba bersarang dipermukaan daun, sehingga daun tergulung akibat tarikan dari jaring-jaring tersebut.

Gejala awal muncul ketika daun menggulung berbentuk kerucut, terutama di bagian permukaan daun, laba-laba tersebut merekatkan daun yang satu dengan bagian daun lainnya sehingga berbentuk kerucut, berbentuk kerucut itu digunakan untuk bersarang dan menempatkan telur laba-laba. Kalau dibiyarkan secara terus menerus daun akan berubah warna menjadi kering dan kecoklatan.

\section{B. Gejala Serangan Penyakit Bibit Karas}

Dari hasil pengamatan di lapangan ditemukan tiga gejala serangan penyakit pada bibit karas yaitu Embun tepung Bercak daun dan Daun menguning. Berdasarkan identifikasi di lapangan, bibit karas ditemukan beberapa gejala penyakit seperti 
embun tepung, bercak daun, dan daun berubah warna atau berwarna kuning. Dari tiga gejala serangan penyakit yang ditemukan di lapangan tersebut rata-rata menyerang bagian daun dan batang bibit karas. Akibat dari gejala serangan tersebut daun dan batang dari bibit karas akan mengalami perubahan fisik dan bentuk.

\section{Embun Tepung}

Gejala serangan penyakit embun tepung didahului adanya bercak putih pada daun bagian bawah, bercak putih tersebut terdiri dari kumpulan konidia dan konidiafor, bercak putih akan menyebar keseluruh permukaan daun dan bahkan bisa menyebar ke ranting dan batang bibit karas.

Bentuk visual cendawan penyebab penyakit embun tepung hanya dapat dilihat dengan menggunakan mikroskop. Penyakit embun tepung berkaitan dengan suhu dan

\section{Bercak Daun}

Gejala serangan penyakit bercak daun mulai muncul saat tanaman berumur 4-6 minggu, berbentuk lingkaran dengan diameter berukuran 1,5-6 $\mathrm{mm}$, bagian pusat bercak transparan dan bagian tepi berwarna coklat tua. Pada kondisi lembab, daun yang terinfeksi menjadi berwarna kuning dan busuk, sedangkan pada kondisi kering daun kelembapan. Perkembangan penyakit pada suhu dingin, kelembapan rendah, dan suasan teduh (Balitbangtan 2006). Sinar matahari juga berpengaruh terhadap epidemi penyakit embun tepung. Pada daerah yang terkena banyak sinar matahari lebih banyak terjadi penyakit embun tepung dari pada daerah yang teduh.

Di persemaian permanen BPDASHL bibit karas diletakkan di deretan bedengan bagian depan yang langsung berhadapan dengan matahari. Kondisi suhu udara di persemaain pada pagi hari rendah dan tinggi pada siang hari. Faktor ini yang menyebabkan gejala serangan embun tepung meningkat. Karena penyakit embun tepung membutuhkan keadaan udara kering untuk melepaskan konidia ke asmosfer, dan membutuhkan udara yang lembab pada saat pembentukan haustorium.

menjadi kering dan rontok, bercak daun akan terus bertambah hingga menjadi merah dan berlobang, pertumbuhan bibit karas akan terganggu karena kurangnya permukaan daun bibit yang sehat, lebih dominan yang terserang terserang dari yang sehat dan serangan lanjutan akan mengakibatkan daun akan rontok. Anggraeni (2009) menyatakan bahwa kerusakan pada daun tanaman dapat 
mengakibatkan proses fotosintesis terganggu. Pada tingkat persemaian hal ini dapat menimbulkan kerugian yang cukup besar karena dapat menyebabkan daun

\section{Daun Bercak dan Menguning}

Perubahan warna daun yang terjadi pada bibit kayu karas disebabkan oleh serangan penyakit. Gejala serangan penyakit yang terjadi ada dipermukaan daun, daun secara perlahan-lahan akan berubah warna menjadi bercak-bercak menguning di keseluruh permukaan daun.

Warna daun menguning kalau dibiyarkan akan mengakibatkan laju pertumbuhan bibit akan terganggu dan daun akan mati dan rontok. Selain dari faktor penyakit, variasi gejala serangan juga dipengaruhi oleh faktor lingkungan seperti tingkat kesuburan tanah dan iklim di sekitar tanaman (Sudiono et al., 2005). Kondisi lingkungan seperti suhu, kelembaban, dan curah hujan di daerah sekitaran penelitian berbeda-beda.

Hal tersebut dapat mempengaruhi respon bibit karas terhadap infeksi beberapa virus yang ditunjukkan dengan adanya gejala serangan yang bervariasi. Air yang berlebih juga dapat menjadi daun bibit karas menjadi menguning dan layu, biasanya menjadi kering, rontok, yang mengakibatkan terhambatnya pertumbuhan bahkan yang lebih fatal akhirnya bibit akan mati, sehingga mengakibatkan gagalnya penanaman. terjadi apabila intensitas air hujan sudah meningkat dan lokasi persemain yang lembab dan agak tergenang, masalah ini dapat diantisipasi dengan memperbaiki lokasi persemaian dan drainase persemain. Selain dari pada itu, daun bibit karas menguning juga dapat disebebkan oleh kekurngan zat unsur hara, sehingga daun menguning dan pertumbuhan bibit menjadi terganggu.

\section{Gejala Serangan Hama Bibit}

\section{Kepayang}

Hasil identifikasi gejala serangan hama pada bibit kepayang di persemain permanen BPDASHL antara lain daun tergunting dan pucuk atau batang terpotong. Hama yang menyerang rata-rata menyerang bagian daun dan pucuk, hama ini juga termasuk dalam golongan serangga pemakan daun dan penggerek tanaman. Gejala serangan hama dapat dilihat dengan adanya gejala daun berubah bentuk, berlubang hingga daun menjadi keriting, terpotong dan tergunting. 


\section{Daun Tergunting}

Gejala serangan hama menyebabkan terhambatnya pertumbuhan tanaman kepayang bahkan kematian pada tanaman. Hal ini dapat menurunkan kualitas dan kuantitas bibit kepayang hal ini dapat merugikan usaha pelaku pembibitan.

Dari hasil pengamatan dilapangan Salah satu gejala serangan hama yang menyerang tanaman kepayang adalah daun tergunting tidak beraturan (di grogoti), bekas gigitan akan berubah warna, gejala serangan di sebebkan oleh ulat pemakan daun, apabila serangan sudah parah akan berakibat bibit akan kerdil dan pertumbuhannya tidak normal atau terganggu. Akibat gejala serangan hama ini proses fotosintesis terganggu dan akan berpengaruh pada pertumbuhan serta produktifitas tanaman.

Tingkat serangan yang terjadi di persemain tidak terlepas pada pengaruh perhatian dan kontrol yang baik dalam usaha pengendalian hama. Kontrol yang baik dan penanganan yang tepat dapat menurunkan populasi hama. Selain kontrol tanaman musuh alami juga sangat membantu dalam menekan perkembangan hama. Banyak parasitoid alami yang mampu menekan perkembangan ulat, baik itu parasitoid larva maupun pupa. Cara pencegahan gejala serangan daun tergunting dengan cara pengendalian alami, melakukan rotasi atau perpindahan tanaman dan pengendalian dengan inseksida guna untuk mengurangi serangan hama.

\section{Pucuk Terpotong}

Berdasarkan hasil pengamatan dilapangan, gejala serangan yang ditemukan pada bibit kepayang berupa pucuk terpotong atau batang terpotong, gejala dan tanda serangan yaitu tanaman mengalami kelayuan kemudian menjadi kering kecoklatan dan kemudian mati, hasil pengamatan terdapat lobang bekas gigitan pada batang serta batang akan mudah patah. Gejala serangan ini ditemukan pada bibit muda, apabila serangan meningkat dapat menurunkan kwalitas dan kuantitas bibit kepayang, hama yang ditemukan di lokasi penelitaian adalah penggerek batang.

Gejala serangan ini disebabkana oleh beberapa faktor salah satunya banyak gulma yang tumbuh di sekitaran lokasi penelitian. Menurut Sembel (2012), pembersihan gulma bukan hanya penting untuk pertumbuhan tanaman yang sehat tetapi juga perlu untuk menjaga agar gulma tidak menjadi tempat berlangsungnya hidup hama 
untuk bertelur atau mendapatkan sumber makanan ataupun hanya untuk tempat tinggal sementara.

Menurut Sinaga (2003) tindakan pengendalian hama penggerek batang yang dapat dilakukan antara lain, kultur teknis melalui pengelolaan lahan, penggunaan varietas bibit unggul, monitoring atau sensus hama.

\section{Gejala Serangan Penyakit Bibit} Kepayang

Pada pengamatan penyakit pada bibit karas dilapangan ada beberapa gejala serangan penyakit yang di temukan Daun Bintik-Bintik dan Daun mengering. Penyakit yang menyerang bibit kepayang adalah daun berubah warna dan bintik-bintik berwarna merah dan daun kering. Bagian yang diserang terdapat di permukaan daun, daun berubah menjadi bintik bintik kemerahan hingga daun mengering.

\section{Daun Bintik-Bintik Berkarat}

Gejala serangan daun bintik-bintik berkarat yang terdapat di daun kepayang awalnya berwara coklat muda, sehingga lama kelamaan daun melepuh membentuk seperti lobang-lobang yang tidak teratur yang dikelilingi oleh lingkaran warna kuning, kalau tidak di antisispasi penyakit ini akan mengakibatkan pertumbuhan bibit terganggu dan menjadi kerontokan.

Pada umumnya bintik-bintik kecil tersebut dikelilingi oleh bagian yang klorosis, walaupun ada juga yang hanya berupa bintik coklat. Penanggulanginya dapat dilakukan dengan penyemprotan insektisida yang tepat, pemisahan bibit kayu kepayang, pemangkasan bagian yang terkena serang dan pemusnahan daun.

\section{Daun Mengering}

Pada persemain BPDASHL setelah di identifikasi bibit kepayang ada sebagi daunnya mengering kecoklatan, menurut salah satu mandor di persemaian permanen penyebab daun mongering seperti terbakar adalah kelebihan pupuk dan serangan ulat kantong, semut dan hama lain yang belum teridentifikasi.

Gejala awal ditandai dengan adanya bercak hitam kecil yang dikelilingi oleh warna kuning muda yang kemudian semakin lama melebar dan daun mengering. Gejala awal terlihat dengan lesi kecil pada daun, lesi ini berwarna kuning pucat, gelap, semakin luas membentuk bintik-bintik cokelat. Rukmana (2002) menyebutkan bahwa penyakit ini tidak menyebabkan kematian akan tetapi pada gejala lanjut daun 
mengering sehingga mengganggu proses fotosintesis yang akan berdampak pada perkembangan bibit.

\section{Gejala Serangan Hama Bibit Jengkol}

\section{Daun Berlobang Serangan Ulat}

\section{Kantong}

Hama ulat kantong merupakan hama polifag yang memakan daun dari berbagai jenis spesies tanaman. Informasi dari keseluruhan siklus hidup ulat kantung sangat penting untuk diketahui sebagai dasar pengendalian hama tersebut. Informasi tentang kelemahan pada siklus hidupnya bisa dipahami dan digunakan untuk mengendalikan hama ulat kantung ini (Kusuma, 2011)

\section{Serangan ulat kantong yang} ditimbulkan pada daun jengkol terlihat seperti berlubang. Pada larva instar awal bagian yang dimakan adalah bagian epidermis atas daun, sedangkan untuk larva

\section{Bagian Daun Terpotong Serangan} Ngengat

Hama lain yang menyerang tanaman jengkol adalah ngengat yang memotong bagian daun sehingga bentuk daun terluka dan tidak sempurna, ngengat juga dapat menyebabkan bercak hitam pada daun melalui infeksi yang dihasilkannya. Ketika instar akhir, bagian yang dimakan adalah epidermis bawah. Naik turunnya serangan ulat kantong ditentukan oleh dinamika populasi larva. Perbedaan tanaman inang akan berpengaruh terhadap kemampuan larva dalam merusak tanaman. Faktor tekanan (stress) dari luar merupakan faktor negatif dalam perkembangan ulat. Pengurangan nutrisi pada tanaman yang mengakibatkan tanaman mengalami stress juga berpengaruh pada perkembangan ulat. Tanaman dengan nitrogen tinggi akan memberikan nutrisi yang baik untuk ulat kantung dalam perkembangannya (Rhainds dkk, 2009 dalam Pangaribuan 2016). Serangan ulat kantong pada daun jengkol menyebabkan daun berlubang mulai dari pinggir hingga bagian tengah daun. Dengan adanya serangan hama ulat kantong ini akan berakibat pada proses pertumbuhan bibit secara keseluruhan.

daun rusak akan berakibat pada terganggunya proses fotosistesis pada tanaman.

\section{E. Gejala Penyakit Jengkol}

\section{Serangan Nekrosis}

Gejalan penyakit yang terdapat pada daun bibit tanaman jengkol adalah adanya bintik-bintik putih atau dikenal dengan 
nekrosis. Tanaman yang sakit dapat dilihat dari gejala yang timbul. Gejala luar yang dapat dilihat pada bagian tanaman yang sakit disebut gejala morfologi. Sedangkan gejala dalam jaringan yang bisa dilihat dengan menggunakan mikroskop disebut gejala histologi. Gejala morfologi meliputi nekrosis, hipoplasis dan hiperplasis.

Nekrosis ditandai oleh adanya regenerasi protoplas dan diikuti dengan kematian sel, jaringan, organ atau seluruh tubuh tanaman. Kerusakan pada klorofil ditimbulkan dengan gejala menguning. Gangguan pada sistem pengangkutan air dapat menyebabkan turgor di dalam sel berkurang sehingga terjadi layu. Untuk menggambarkan jaringan sakit yang menunjukkan gejala kebasah-basahan dan tembus cahaya dugunakan istilah hidrosis. Hidrosis ini biasanya mendahului perkembangan gejala seperti busuk, barcak dan hawar.

\section{Cendawan Putih}

Spora cendawan yang jatuh pada permukaan tanaman akan berkecambah bila kondisi lingkungan mendukung. Faktorfaktor lingkungan yang penting adalah adanya lapisan air dan/atau kelembaban tinggi dan suhu (umumnya antara $15-30^{\circ} \mathrm{C}$ ).
Faktor lainnya adalah $\mathrm{pH}$, oksigen dan karbondioksida dan unsur hara.

Stadia infeksi dalam patogenesis adalah asosiasi antara patogen dengan jaringan inangnya. Proses penyakit mulai bila telah terjadi respon yang merusak pada bagian tumbuhan yang diserang. Waktu antara jatuhnya inokulum pada tempat infeksi sampai awal terjadinya penyakit merupakan periode inkubasi. Secara praktis periode inkubasi adalah waktu antara inokulasi sampai timbulnya gejala.

Perkembangan penyakit umumnya terjadi pada musim waktu hari-hari basah, dan pada tanaman yang dipupuk $\mathrm{N}$ secara berlebihan. Hal ini menunjukkan bahwa faktor lingkungan, termasuk suhu, kelembaban, cahaya, zat hara dan $\mathrm{pH}$ tanah berpengaruh terhadap perkembangan penyakit cendawan. Untuk perkembangan penyakit setidaknya diperlukan adanya tiga faktor, yaitu tumbuhan yang rentan, patogen yang infektif dan lingkungan yang sesuai bagi perkembangan patogen. Perubahan pada faktor lingkungan dapat berpengaruh terhadap patogen atau tumbuhan atau keduanya. 


\section{Bercak Kuning}

Bercak pada daun jengkol merupakan salah satu indikasi adanya serangan penyakit. Bercak pada daun ini dikenal dengan penyakit antraknosa. Penyebab antraknosa adalah cendawan (jamur). Gejala antraknosa ditandai dengan munculnya bercak berwarna kuning atau hijau muda dan berbentuk bulat. Lama kelamaan bercak akan berubah menjadi coklat dan berbintik hitam yang merupakan spora jamur. Bercak tersubut lama kelamaan akan menyebabkan busuk pada daun tanaman. Cendawan penyebab penyakit antraknosa ini bisanya yaitu Colletroticum sp.dan Gloeosporium s p.

Pertumbuhan cendawan ini dipengaruhi oleh faktor lingkungan, seperti suhu, kelembaban, serta kebersihan lingkungan sekitar. Suhu optimum untuk pertumbuhan cendawan ini berkisar 24$30^{\circ} \mathrm{C}$ dengan kelembaban relatif antara 80$92 \%$. Penyebab antraknosa berpotensi tinggi menyerang pada musim hujan. Cendawan ini dapat menular ke tanaman lain lewat percikan air.

Cara menangani penyakit antraknosa ini salah satunya adalah dengan melakukan pemupukan yang tepat dan berimbang. Jika ada salah satu bagian daun tanaman yang terserang, maka buanglah daun tanaman tersebut agar tidak menular ke bagian yang lain. Untuk mengurangi kelembaban, lakukan pemangkasan daun daun tua. Jika serangan sudah parah, maka lakukan penyemprotan dengan pestisida.

\section{Bercak Hitam}

Infeksi jamur menjadi penyebab paling umum munculnya bercak hitam pada daun tanaman. Meskipun demikian, setiap tanaman memiliki kerentanan yang berbeda terhadap berbagai jenis jamur. Infeksi jamur adalah tanda tanaman terlalu lembab atau air terlalu lama menempel di daun. Infeksi semacam ini secara umum disebut bercak daun.

Buang daun yang terkena bercak hitam untuk mengurangi kontaminasi lebih lanjut. Infeksi jamur biasanya tidak berbahaya jika ditangani lebih awal, dan tidak menyebabkan kerusakan permanen setelah penyebabnya diperbaiki. Menjaga tanaman agar lebih kering dan memastikan daunnya tidak basah adalah pencegahan dan pengobatan terbaik. 
Penyebab penyakit pada tumbuhan ada dua yaitu patogen dan non patogen. Patogen adalah organisme yang mempunyai kemampuan menyebabkan penyakit dalam bentuk organisme hidup atau disebut pula faktor biotik. Organisme yang tergolong kedalam patogen adalah jamur, bakteri, virus, mikoplasma, spiroplasma dan riketsia.

Sedangkan organisme yang tergolong non patogen antara lain yang berasal dari faktor fisik, kimia dan faktor alam (Yudiarti, 2007). Infeksi penyakit pada tanaman melalui beberapa proses, Anggraeni (2007) menyatakan bahwa tahap awal rangkaian proses terjadinya penyakit adalah kontak agen patogenik dengan inang yang rentan, diikuti oleh infeksi ke dalam jaringan inang, kemudian perkembangan interaksi antara patogen dan inang yang rentan dan pada akhirnya akan timbul penyakit. Penyakit pada tanaman dapat diketahui dengan mengamati tanda dan gejala yang muncul pada tanaman yang diduga terserang patogen.

Gejala adalah karakteristik yang muncul pada tanaman sebagai hasil interaksi patogen dengan tanaman tersebut contohnya layu pada semai dan bercak pada daun (Semangun, 2001). Tanda adalah adanya bagian tubuh organisme patogen yang terdapat pada tubuh tanaman inang, misalnya adanya serbuk spora fungi patogen penyebab panyakit.

Tanda awal penyakit bercak daun pada bibit di persemaian adalah adanya noda atau bercak-bercak pada permukaan daun dengan batas yang jelas. Bercak daun yang terbentuk umumnya berwarna coklat dengan dikelilingi oleh batasan yang berwarna lebih gelap. Bentuk bercak daun bervariasi dan cenderung tidak beraturan. Ukuran bercak semakin membesar dari waktu ke waktu dan akan semakin meluas hingga menutupi seluruh bagian daun. Pada bercak daun yang telah meluas batas warna antara bagian tengah dan tepi akan semakin jelas, pada bagian tengah bercak warnanya agak lebih terang dibandingkan dengan bagian tepi bercak.

\section{F. Gejala Serangan Hama Petai}

\section{Gejala Daun Kering Dan Rontok Akibat} Serangan Ngengat

Hama ngengat adalah salah satu hama pada bibit tanaman petai. Hama ini menyerang pada daun bibit tanaman petai yang menyebabkan daun kering dan rontok. Bukan saja karena kehadirannya mengganggu proses pertumbuhan tanaman, 
namun serangan hama ngengat seringkali menyebabkan bibit mengalami kerusakan dan kematian.

Hama yang menyerang bibit tanaman petai ini dapat merusak tanaman mulai dari fase penyemaian hingga ditanam dilapangan. Secara fisik, hama ngengat dapat dibedakan menjadi 4 jenis, yakni: ngengat kuning, ngengat putih, ngengat bergaris, serta ngengat merah jambu. Meskipun memiliki ciri fisik dan karakter yang berbeda, ke empat jenis ngengat tersebut sama berbahayanya.

Ngengat memiliki fase hidup yang lengkap meliputi telur-larva-pupa-ngengat. Yang dikenal sebagai hama adalah saat ngengat dalam fase larva, karena larva inilah yang akan bergerak dan mulai memakan sari pati tumbuhan. Pengendalian hama ini dapat dilakukan dengan cara menggunakan insektisida butiran dengan dosis $12 \mathrm{~kg} / 1000$ $\mathrm{m} 2$.

\section{G. Gejala Serangan Penyakit Petai}

\section{Daun Menguning Sebagian}

Gejala mosaik kuning pada daun berupa perbedaan warna yang sangat mencolok pada daun, yakni kuning tua dan hijau tua. Pada gejala daun menguning maupun mosaik kuning tidak terjadi perubahan ukuran dan bentuk daun, gejalagejala tersebut terutama ditemukan pada daun-daun muda. Akibatnya pertumbuhan tanaman terhambat dan mengurangi hasil, dan bisa menyebabkan kehilangan hasil total jika tanaman terinfeksi selama awal pertumbuhan.

\section{Bercak Cokelat Dan Kering}

Penyakit bercak daun coklat ditemukan pada bibit tanaman petai hal ini diduga disebabkan oleh media tanam yang kurang subur, atau kahat unsur hara tertentu. Penyakit ini dapat menyerang pada saat persemaian dan dapat mengakibatkan tanaman mati karena busuk pada koleoptil, batang dan akar. Serangan juga dapat terjadi pada daun, apabila daun bibit petai terserang maka mutu bibit akan menurun.

Hubungan antara terjadinya penyakit dengan ketersediaan unsur hara tanah sangat erat. Tanaman yang kurang sehat sangat mudah terserang penyakit ini. Pada kondisi tanah yang kahat unsur kalium penyakit bercak coklat dapat menimbulkan kerugian. Faktor lain yang berpengaruh adalah sistem drainase yang tidak baik, sehingga mengganggu terserapnya unsur-unsur hara.

Gejala yang paling umum dari penyakit ini adalah adanya bercak berwarna 
coklat tua, berbentuk oval sampai bulat, berukuran sebesar, pada permukaan daun. Gajala khas penyakit ini adalah adanya bercak coklat pada daun berbentuk oval yang merata di permukaan daun. Bercak yang masih muda berwarna coklat gelap atau keunguan berbentuk bulat.
H. Frekuensi dan Intensitas Serangan Hama dan Penyakit

1. Frekuensi Serangan Hama pada Bibit Karas, Kepayang, Jengkol dan Petai.

Frekuensi serangan hama pada bibit karas, kepayang, jengkol dan petai ditampilkan pada Tabel 4.

Tabel 4. Frekuensi Serangan Hama Bibit Karas, Kepayang, Jengkol dan Petai.

\begin{tabular}{llll}
\hline Jenis Bibit & Nama Latin & FS (\%) & Tingkat Kerusakan \\
\hline Karas & Aquilaria malaccensis & 20,55 & Rusak Ringan \\
Kepayang & Pangium edule & 23,26 & Rusak Ringan \\
Jengkol & Archidendron pauciflorum & 19,19 & Rusak Ringan \\
Petai & Parkia speciosa & 22,01 & Rusak Ringan \\
\hline Rata-rata & & 21,25 & Rusak Ringan \\
\hline
\end{tabular}

Sumber: Data Olahan 2021

2. Frekuensi Serangan Penyakit pada

Bibit Karas, Kepayang, Jengkol dan

Petai.
Frekuensi serangan Penyakit bibit karas, bibit kepayang, jengkol dan petai ditampilkan pada Tabel 5.

Tabel 5. Frekwuensi Serangan Penyakit Bibit Karas, Kepayang, Jengkol dan Petai.

\begin{tabular}{llll}
\hline Jenis Bibit & Nama Latin & FS (\%) & Tingkat Kerusakan \\
\hline Karas & Aquilaria malaccensis & 22,45 & Rusak Ringan \\
Kepayang & Pangium edule & 30,68 & Rusak Sedang \\
Jengkol & Archidendron pauciflorum & 28,15 & Rusak Sedang \\
Petai & Parkia speciosa & 23,65 & Rusak Ringan \\
\hline Rata-rata & & 26,23 & Rusak Sedang \\
\hline
\end{tabular}

Sumber: Data Olahan 2021

3. Intensitas Serangan Hama pada Bibit

Karas, Kepayang, Jengkol dan Petai.
Intensitas serangan Hama bibit karas, bibit kepayang, jengkol dan petai ditampilkan pada Tabel 6. 

Vol. 17 No. 1 Januari 2022

Tabel 6. Intensitas Serangan Hama Bibit Karas, Kepayang, Jengkol dan Petai.

\begin{tabular}{llll}
\hline Jenis Bibit & Nama Latin & IS (\%) & Tingkat Kerusakan \\
\hline Karas & Aquilaria malaccensis & 11,39 & Rusak Ringan \\
Kepayang & Pangium edule & 11,64 & Rusak Ringan \\
Jengkol & Archidendron pauciflorum & 23,06 & Rusak Ringan \\
Petai & Parkia speciosa & 25,43 & Rusak Ringan \\
\hline Rata-rata & & 17,88 & Rusak Ringan \\
\hline
\end{tabular}

Sumber: Data Olahan 2021

\section{Intensitas Serangan Penyakit pada}

Bibit Karas, Kepayang, Jengkol dan

Petai.
Intensitas serangan Penyakit pada bibit karas, bibit kepayang, jengkol dan petai disajikan pada Tabel 7.

Tabel 7. Intensitas Serangan Penyakit Bibit Karas, Kepayang, Jengkol dan Petai.

\begin{tabular}{llll}
\hline Jenis Bibit & Nama Latin & IS $(\%)$ & Tingkat Kerusakan \\
\hline Karas & Aquilaria malaccensis & 12,44 & Rusak Ringan \\
Kepayang & Pangium edule & 18,07 & Rusak Ringan \\
Jengkol & Archidendron pauciflorum & 33,02 & Rusak Sedang \\
Petai & Parkia speciosa & 27,55 & Rusak Sedang \\
\hline Rata-rata & & 22,77 & Rusak Ringan \\
\hline
\end{tabular}

Sumber: Data Olahan 2021

\section{KESIMPULAN DAN SARAN}

\section{A. Kesimpulan}

Berdasarkan hasil penelitian ini dapat disimpulkan sebagai berikut:

1. Gejala serangan hama yang di temukan pada bibit karas adalah walang sangit, kutu putih, dan belalang. Pada bibit kepayang adalah kutu kebul atau kutu kuning, ulat kantong, semut. Pada bibit jengkol adalah ulat kantong dan ngengat. Pada bibit petai adalah ngengat.

2. Gejala penyakit yang ditemukan pada bibit karas adalah embun tepung, bercak daun, daun menguning. Pada bibit kepayang adalah daun binik-bintik dan 
daun mengering. Pada bibit jengkol adalah nekrosis, cendawan putih, bercak kuning, bercak hitam dan daun kering. Pada bibit tanaman petai adalah daun menguning, bercak cokelat dan kering.

3. Frekwensi serangan hama pada 4 jenis bibit rata-rata sebesar $22,01 \%$ termasuk kategori rusak ringan. Frekwensi serangan penyakit pada pada 4 jenis bibit rata-rata sebesar $26,23 \%$ termasuk kategori rusak sedang.

4. Intensitas serangan hama pada pada 4 jenis bibit rata-rata sebesar $17,88 \%$ termasuk kategori rusak ringan. Intensitas serangan penyakit pada pada 4 jenis bibit rata-rata sebesar $22,77 \%$ termasuk kategori rusak ringan.

\section{B. Saran}

Perlu dilakukan penelitian lebih lanjut terhadap serangan hama dan penyakit ketika bibit ditanam dilapangan.

\section{DAFTAR PUSTAKA}

Anggraeni, I. 2007. Diagnosis Penyakit Baercak Daun pada Jati (Tectona grandis Lf). Prosisding Sintesa Hasil Litbang Hutan Tanaman. p 217-223.

Koteng, Suryantini, R Dan Herawatiningsih, R. 2019. Identifikasi Serangga Hama Dan Tingkat Kerusakan Bibit Trembesi
(Samanea Saman (Jacq.). Merr. Di Areal BPDASHL Kapuas Kota Pontianak. Jurnal Hutan Lestari. Vol. 7 (3) : $1058-1067$

Pangaribuan R. 2016. Tingkat Serangan Ulat Kantung Cremastopsyche pendula Joannis Terhadap Tanaman Kelapa Sawit Menghasilkan Dan Belum Menghasilkan Di Rambong Sialang Estate Ptpp. London Sumatera Indonesia. Skripsi. Program Studi Agroekoteknologi Fakultas Pertanian Universitas Sumatera Utara.

Rukmana, R., dan Uu S., 2002. Hama Tanaman dan Teknik Pengendalian. Kanisius, Yogyakarta.

Satriani, Burhanuddin, Awaludin. 2020. Analisis Pengelolaan Persemaian Permanen Bibit pada Balai Pengelolaan Daerah Aliran Sungai Hutan Lindung Palu Poso. Jurnal Kolaboratif Sains ISSN 2623-2022. Volume 03, Nomor 08. P. 407-414.

Sinaga, S. 2003. Dasar-dasar Ilmu Penyakit Tumbuhan. Penebar Swadaya. Jakarta Suharti, T. Kurniaty R , Siregar N, dan Darwiati, W. 2015. Identifikasi Dan Teknik Pengendalian Hama Dan Penyakit Bibit Kranji (Pongamia Pinnata). Jurnal Perbenihan Tanaman Hutan. Vol.3 No.2, Desember 2015 : 91-100. ISSN : 2354-8568

Triwibowo H, Jumani, dan Emawati, H. 2014. Identifikasi Hama Dan Penyakit Shorea Leprosula Miq Di Taman Nasional Kutai Resort Sangkima Kabupaten Kutai Timur Provinsi Kalimantan Timur. Jurnal AGRIFOR Volume XIII Nomor 2, ISSN : 1412 6885. P. 175-184

Yudiarti, T. 2007. Ilmu Penyakit Tumbuhan. Graha Ilmu. Yogyakarta. 